\section{Proteomic analysis of enamel matrix using a two-dimensional protein fractionation system}

Yamakoshi Y, Hu JC-C, Zhang H, Iwata T, Yamakoshi F, Simmer JP. Proteomic analysis of enamel matrix using a two-dimensional protein fractionation system. Eur $J$ Oral Sci 2006; 114 (Suppl. 1): 266-271 @ Eur J Oral Sci, 2006

Our objectives in this study were to perform separate proteomic analyses of porcine soft and hard enamel matrices, using the ProteomeLab PF-2D System, to compare the contents of the hard and soft enamel and to identify matrix constituents that are absent from the early maturation stage. Developing first permanent molars were dissected from 6-month-old pigs. Both immature and mature enamel samples were obtained by scraping the secretory-stage (soft) and maturation-stage (hard) enamel, respectively. Enamel matrix samples were sequentially extracted and fractionated with $50 \mathrm{mM}$ phosphate buffer ( $\mathrm{pH} 7.4)$ and then with $50 \mathrm{mM}$ carbonate buffer ( $\mathrm{pH} \mathrm{10.8).}$ The neutral enamel extract was separated into four fractions by successive ammonium sulfate precipitations. The alkaline enamel extract was separated into four fractions by ion-exchange chromatography. These eight extracts from both the soft and hard enamel were injected for chromatofocusing. Soft enamel fractions containing constituents absent from the hard enamel were further separated by reverse-phase highperformance liquid chromatography. The major soft enamel constituents absent from the hard enamel were acidic glycoproteins, corresponding to the $32-\mathrm{kDa}$ enamelin, and the 29-, 27-, 15-, 13-, 8- and 6-kDa C-terminal fragments of ameloblastin. Loss of these glycoproteins is associated with a post-transition increase in enamel mineralization.
Yasuo Yamakoshi ${ }^{1}$, Jan C.-C. Hu', Hengming Zhang ${ }^{1}$, Takanori Iwata ${ }^{1,2}$, Fumiko Yamakoshi ${ }^{1}$, James $P$. Simmer ${ }^{1}$

${ }^{1}$ University of Michigan Dental Research Laboratory, Ann Arbor, MI, USA; ${ }^{2}$ Tokyo Medical and Dental University, Tokyo, Japan
James P. Simmer, University of Michigan

Dental Research Laboratory, 1210 Eisenhower Place, Ann Arbor, MI 48108, USA

Telefax: +1-734-9759329

E-mail: jsimmer@umich.edu

Key words: amelogenesis; enamel; enamelin; PF-2D system; proteomics

Accepted for publication October 2005
Dental enamel forms according to instructions encoded in the genetic blueprint. The genetic instructions are executed by proteins, some of which are secreted into the enamel matrix where they regulate mineralization. These secreted proteins control the initiation, growth, and organization of the forming enamel crystals $(1,2)$. Defects in the genes encoding these proteins result in inherited enamel malformations (3). Understanding the processes involved in the formation of normal or diseased enamel requires identification and characterization of all the critical molecular participants involved in these processes.

Previously we reported a comprehensive strategy for isolating enamel matrix proteins (4). This strategy evolved from the non-dissociative, $\mathrm{pH}$-based extractions developed at Tsurumi University (5-7). The non-dissociative method has been used extensively to isolate and characterize porcine enamel proteins, including amelogenin $(5,7-10)$ and non-amelogenin $(11,12)$ enamel proteins such as enamelin $(13-17)$, ameloblastin $(18,19)$, and KLK4 (20-22). In this report we improve the strategy for comprehensive fractionation of enamel proteins by adding chromatofocusing.

Chromatofocusing is a recently improved technology that separates proteins according to their isoelectric point (pI), using high-performance liquid chromatogra- phy (HPLC). In this study we use the PF-2D system from Beckman Coulter (Fullerton, CA, USA), which separates proteins in solution according to their pI. The useful $\mathrm{pH}$ range is between 8.5 and 4.0, and the resolution can be set as low as $0.1 \mathrm{pH}$ unit. Above and below this range, the proteins are collected essentially as a single fraction (i.e. those with pIs of $>8.5$ are one fraction, and those with pIs of $<4.0$ are another fraction). The $\mathrm{pI}$ fractions represent the first-dimension separation. The PF-2D system is programmed to automatically inject each $\mathrm{pH}$ fraction onto a reverse-phase column for a second-dimension separation. The PF-2D system generates highly reproducible chromatographic profiles and protein separations. These features make it ideally suited for comparing and contrasting protein profiles from two sources.

We elected to use the PF-2D system, rather than the standard proteomic technique of gel isoelectric focusing followed by sodium dodecyl sulphate-polyacrylamide gel electrophoresis (SDS-PAGE), because small proteins $(<5 \mathrm{kDa})$ tend to run off two-dimensional (2D) gel electrophoresis and because we wanted a system that would allow us to isolate protein for future functional studies. In this report we show the results of chromatofocusing the eight major enamel protein fractions generated by following a comprehensive system developed 
for the isolation of porcine enamel protein (4). The chromatofocusing was performed separately, but following an identical protocol, on eight fractions obtained from soft, secretory-stage enamel, and hard, postsecretory (or maturation) stage enamel.

Small amounts of acidic, crystal-binding proteins (previously referred to as enamelins) have been proposed to inhibit crystallite maturation (growth in width and thickness) during the secretory stage, accounting for the observation that secretory-stage enamel crystallites can be $\approx 1000$ times longer than they are thick. Theoretically, this effect could be achieved if inhibitors become bound to growth sites, such as kinks or steps on the sides of the crystal where ions join the crystal lattice. As only small amounts of inhibitor need to be present for inhibition to occur, we did not attempt to identify all matrix constituents that decreased in amount (all did); instead, we looked for enamel proteins that were present in the soft enamel (SE) extracts (when inhibition appears to occur), but were absent from the hard enamel (HE) extracts, where substantial enamel maturation occurs. By comparing the protein profiles of the $\mathrm{pI}$ fractions from the SE and the $\mathrm{HE}$, we were able to identify enamel matrix constituents that are temporally associated with the inhibition of enamel crystallite growth in width and thickness.

\section{Material and methods}

All experimental procedures involving the use of animals were reviewed and approved by the Institutional Animal Care and Use Program at the University of Michigan.

\section{Preparation of both SE and HE}

Tooth germs of permanent molars were surgically extracted from the maxillae and mandibles of 6-month-old pigs at the Michigan State University Meat Laboratory (East Lansing, MI, USA). The enamel organ epithelia and dental pulp tissue were removed using tissue forceps. The soft, cheeselike enamel (i.e. SE) was separated from the crowns using a spatula. Early maturation-stage enamel samples (i.e. HE) were obtained by scraping the remaining hard, chalky enamel.

\section{Separation of SE and HE extracts}

Soft or hard enamel scrapings were sequentially extracted $(10 \mathrm{ml} / 1 \mathrm{~g})$ to obtain a neutral extract, an alkaline extract, and residual insoluble material. The neutral extract was obtained by homogenizing the enamel shavings in Sörensen buffer (made by mixing $\mathrm{Na}_{2} \mathrm{HPO}_{4}$ and $\mathrm{KH}_{2} \mathrm{PO}_{4}$ to achieve a final phosphate concentration of $50 \mathrm{mM}$ and a $\mathrm{pH}$ of 7.4). Material not soluble in the neutral extract was obtained by centrifugation. The pellet was resuspended in carbonate buffer, made by mixing bicarbonate $\left(\mathrm{NaHCO}_{3}\right)$ and carbonate $\left(\mathrm{Na}_{2} \mathrm{CO}_{3}\right)$ to a final concentration of $50 \mathrm{mM}$, and a $\mathrm{pH}$ of $10.8(5,6)$, and homogenized. The neutral extract and alkaline extracts included proteinase inhibitors [5 mM 1,10 phenanthroline (Sigma, St Louis, MO, USA); and Protease Inhibitor Cocktail Set III (Novagen, Madison, WI, USA)]. Material not soluble in the alkaline extract was pelleted by centrifugation and designated as the residual insoluble material.

\section{Fractionation of the neutral extract}

The neutral extract of SE or HE was raised to $40 \%$ saturation by the addition of ammonium sulfate, and the precipitate was removed by centrifugation (fractions SE1 or HE1, respectively). The supernatant was raised to $65 \%$ saturation and the precipitate was pelleted by centrifugation. The $40-65 \%$ saturation pellet was divided into acidsoluble (SE2 or HE2) and acid-insoluble (SE3 or HE3) fractions by resuspending in $0.5 \mathrm{M}$ acetic acid, with insoluble material being separated by centrifugation. The 40 $65 \%$ saturation supernatant (i.e. fractions SE4 or HE4) was concentrated and stored at $-20^{\circ} \mathrm{C}$.

\section{lon-exchange chromatography}

The alkaline extract of SE or $\mathrm{HE}$ was applied to a Q-Sepharose Fast Flow column $(1.6 \mathrm{~cm} \times 20 \mathrm{~cm}$; Amersham Pharmacia, Uppsala, Sweden) and eluted with a linear gradient (0- $0.25 \mathrm{M}$ buffer B). Buffer A was $50 \mathrm{mM}$ Tris$\mathrm{HCl}$ containing $6 \mathrm{M}$ urea; buffer $\mathrm{B}$ was buffer A containing $0.5 \mathrm{M} \mathrm{NaCl}$.

\section{Sample preparation for 2D separation of liquid}

In order to minimize the effect of buffer differences, enamel samples were exchanged with start buffer using a PD-10 column (Amersham Biosciences). Each enamel fraction ( $\approx 3.5 \mathrm{mg}$ ) was diluted to $2.5 \mathrm{ml}$ with start buffer, and the diluted solution was applied onto a PD-10 column. A 3.5-ml volume of eluent was collected after loading an equal amount of start buffer. All buffer-changed samples were stored at $4^{\circ} \mathrm{C}$ for $1-5 \mathrm{~d}$.

\section{D liquid separation of enamel fractions}

The 2D liquid separation of enamel fractions was carried out by high-performance chromatofocusing (HPCF) in a first-dimension fractionation step followed by non-porous reverse-phase (NPS RP) HPLC of these fractions in a second-dimension step using a ProteomeLab PF2D system (Beckman Coulter).

High-performance chromatofocusing was performed on a PF2D-HPCF column $(250 \times 2.1 \mathrm{~mm})$ (Beckman Coulter). Two buffers - the equilibration/start buffer and the elution buffer, adjusted to $\mathrm{pH} 8.6$ and $\mathrm{pH} 4.2$ by iminodiacetic acid, respectively - were used to generate the $\mathrm{pH}$ gradient on the column. The column was equilibrated with start buffer until a stable $\mathrm{pH}$ and an ultraviolet $(280 \mathrm{~nm})$ absorbance were achieved. The buffer-exchanged sample $(0.2-0.5 \mathrm{mg})$ was applied to the column and the eluent from HPCF separation was collected from $\mathrm{pH} 8.6-4.2$ in $0.3-\mathrm{pH}$ unit intervals. The collection process was controlled using 32 KARAT software.

Non-porous RP-HPLC was performed using a PF2DHPRP column $(4.6 \times 30 \mathrm{~mm})($ Beckman Coulter $)$. The column was equilibrated with $0.1 \%$ trifluoroacetic acid (TFA) and eluted with a linear acetonitrile gradient $(0-100 \%$ / $30 \mathrm{~min}$ ) containing $0.08 \%$ TFA, at a flow rate of $0.75 \mathrm{ml} \mathrm{min}-1$, at $50^{\circ} \mathrm{C}$. The effluent was continuously monitored by a UV monitor set at a wavelength of $214 \mathrm{~nm}$ and was collected into 96-deep-well titer plates every $45 \mathrm{~s}$, from 2 to $32 \mathrm{~min}$. The plates were sealed with mat covers 
and stored at $-20^{\circ} \mathrm{C}$. After $2 \mathrm{D}$ liquid separation, the chromatographic data for the enamel fractions were processed using PROTEOVUE software (Beckman Coulter) to generate image gels, which are simulated electrophoretograms.

\section{SDS-page}

Enamel fractions were separated by SDS-PAGE on $16 \%$ gels and stained with stains-all or silver.

\section{Automated Edman degradation}

Automated Edman degradation was performed with an Applied Biosystems Procise $494 \mathrm{cLC}$ protein sequencer at the W.M. Keck Facility at Yale University.

\section{Results}

The HE and SE were separated from the unerupted, developing molars of 6-month-old pigs. The SE and HE scrapings were isolated in exactly the same way (Fig. 1A). First, the proteins that could be extracted with phosphate buffer at neutral $\mathrm{pH}$ were obtained and designated as the neutral fractions. The material not dissolved in neutral buffer was extracted with alkaline buffer and designated the alkaline extracts. Through a series of ammonium-sulfate precipitations, the neutral extracts were separated into four fractions (E1-E4), while the alkaline extracts were separated into four fractions by ion-exchange chromatography (E5-E8; Fig. 1B). Each of these primary fractions (eight from the $\mathrm{SE}$ and eight from the $\mathrm{HE}$ ), were further fractionated using the PF-2D, which combines chromatofocusing and NPS HPLC. The 2D separations of the fractions from the neutral extracts of the soft and hard enamel are shown in Fig. 2 (Fig. 2A, SE1/HE1; Fig. 2B, SE2/HE2; Fig. 2C, SE3/HE3; Fig. 2D, SE4/HE4). The 2D separations of the ion exchange fractions of the alkaline extracts of the soft and hard enamel are shown in Fig. 3 (Fig. 3A, SE5/HE5; Fig. 3B, SE6/HE6) and Fig. 4 (Fig. 4A, SE7/HE7; Fig. 4B, SE8/HE8).

Comparing the chromatofocusing profiles of equivalent primary fractions from the SE and HE revealed that many molecular components are reduced or absent from the HE. The most dramatic differences, however, are in fractions E2 and E3 (Fig. 2B,C). Fractions E2 and E3 correspond to the acid-soluble and acid-insoluble components of the neutral extract that precipitated between 40 and $65 \%$ saturation with ammonium sulfate. PF-2D fractions unique to the SE extracts, that is, those not represented in the equivalent $\mathrm{HE}$ fractions, were analyzed by SDS-PAGE and N-terminal (Edman) sequencing (Fig. 4).

The 2D chromatograms, SDS-PAGE, and Edman sequences for SE2 chromatofocusing peaks 22, 23 and 25 (pI range: 4.08-4.69) corresponded to the $32-\mathrm{kDa}$ enamelin (Fig. 4A) $(15,17)$. For SE3, chromatofocusing peaks 18 and 19 (pI range: 5.15-5.66) contained the 27and $29-\mathrm{kDa}$ calcium-binding proteins corresponding to the ameloblastin $\mathrm{C}$ terminus (Fig. 4B) (23), as well as
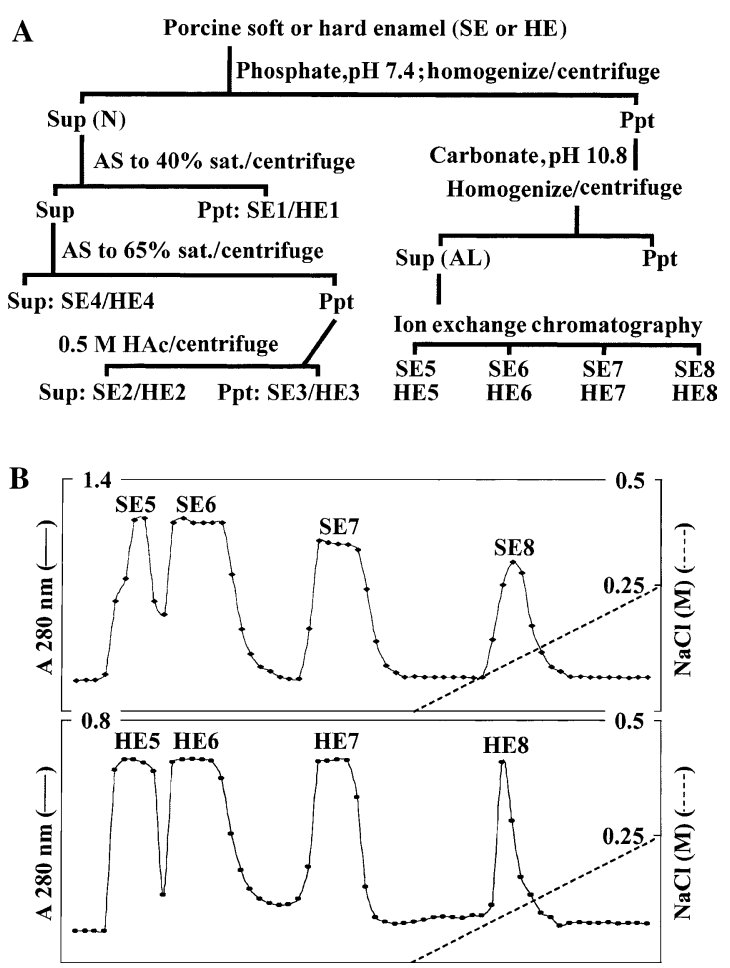

Fig. 1. Preparation of eight primary enamel fractions. A schematic diagram of the isolation procedures used to produce four neutral-extract fractions (E1-E4) and four alkaline-extract fractions (E5-E8) is shown in (A). AS, ammonium sulfate; HAc, acetic acid; HE, hard enamel; N, neutral extract; Ppt, precipitate; SE, soft enamel; Sup, supernatant. The chromatograms for fractionation of the soft- and hard-enamel alkaline extracts by ion-exchange chromatography are shown in (B). Each dot on the chromatogram indicates a tube change on the collector. Numbers on the left (1.4 and 0.8) indicate the absorbance at $280 \mathrm{~nm}$ at the top of the chromatogram. A dashed line shows the $\mathrm{NaCl}$ gradient. The numbers on the right $(0.5$ and 0.25$)$ indicate the molarity of $\mathrm{NaCl}$ entering the column.

smaller ameloblastin C-terminal cleavage products migrating at 6 and $8 \mathrm{kDa}$. The SE3 chromatofocusing peaks 22,24 , and 25 (pI range: 4.23-4.57) corresponded to the $32-\mathrm{kDa}$ enamelin and to the $13-$ and $15-\mathrm{kDa}$ C-terminal cleavage products (19). Albumin was also detected, but this was considered to be a contaminant from serum.

\section{Discussion}

The key to understanding enamel biomineralization is to learn how secreted enamel proteins initiate, extend, and organize hydroxyapatite crystals. Before rational hypotheses can be framed concerning the molecular mechanisms of enamel matrix-mediated biomineralization, it is necessary to identify and characterize the proteins that catalyze it. Previously, we described a comprehensive system for the isolation of enamel proteins (4). Since this strategy was devised, protein isolation technology that permits the fractionation of proteins in solution according to their isoelectric points (chromatofocusing) 


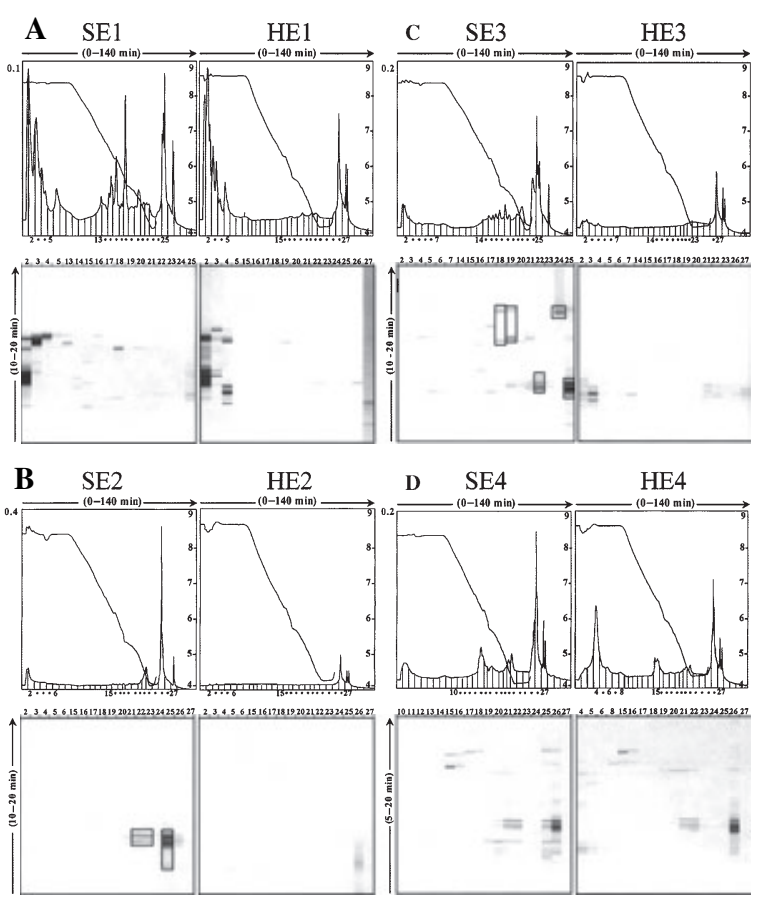

Fig. 2. Two-dimensional separation of the four neutral-extract fractions: SE1/HE1 (A), SE2/HE2 (B), SE3/HE3 (C) and SE4/ HE4 (D). (HE, hard enamel; SE, soft enamel.) At the top of each section is the chromatogram for the first-dimension runs (chromatofocusing). The number on the left at the top of the chromatogram indicates the absorbance at $280 \mathrm{~nm}$. Labeled arrows at the top of each chromatogram indicate that the chromatofocusing column was run for $140 \mathrm{~min}$. Starting on the upper left and moving to the right and then diagonally down is the $\mathrm{pH}$ reading of the material leaving the column. The calibrations for these $\mathrm{pH}$ readings are on the right and range from 4 to 9 . After the $\mathrm{pH}$ gradient bottoms out (at the right) there are often salt peaks that do not contain protein. Vertical lines extending up to the absorbance line mark tube changes on the collector. Tube changes occurred at every 0.3 decrease in $\mathrm{pH}$. The numbers at the bottom indicate the fraction number, with a dot indicating an increase of 1.0 from the previous number or dot. These fraction numbers correspond to the lane numbers of the image gels for the second-dimension run (below). The image gels are a computer-generated interpretation of each chromatogram (read at $214 \mathrm{~nm}$ ) from the non-porous high-performance liquid chromatography (NPS HPLC) run. The boxed bands on the image gels in (B) and (C) correspond to fractions that were chosen for further characterization because of their absence from the equivalent hard enamel fraction.

has improved. In this study, we report the first application of this technology to the fractionation of enamel proteins.

We find that the chromatofocusing step is a welcome addition to the repertoire of HPLC techniques we employ to isolate enamel proteins. When partially purified enamel proteins are applied to the chromatofocusing column, they do not clog it, as has been the experience of laboratories studying more crude extracts. We have used the same column for over 30 runs, without an increase in column pressure. We do, however, experience problems with protein aggregation. In some enamel fractions, protein aggregates pass straight through the chromato-
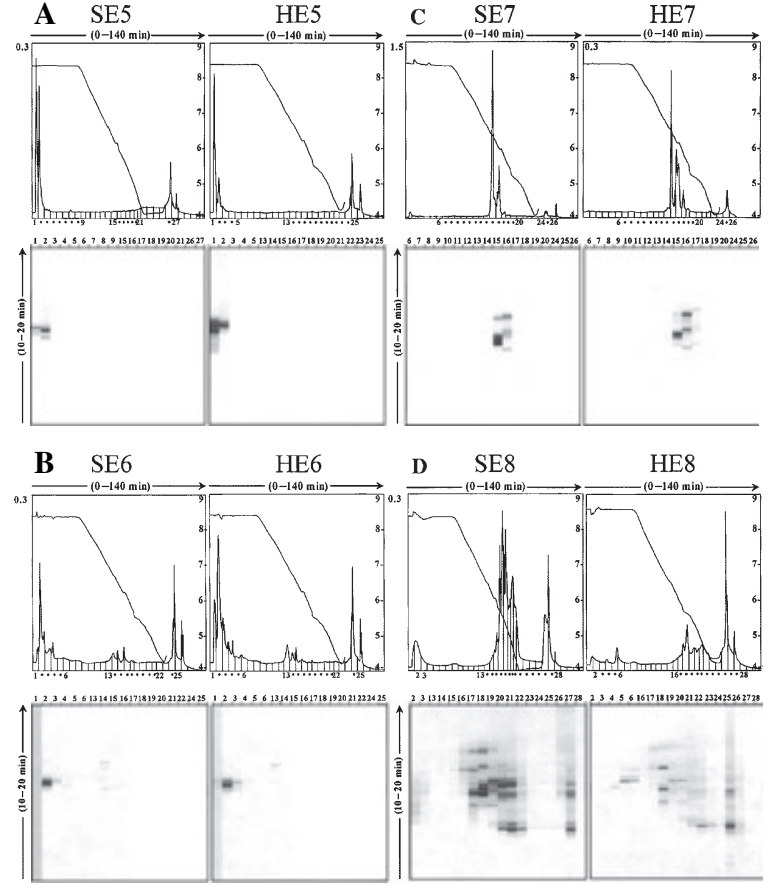

Fig. 3. Two-dimensional separation of the four ion-exchange fractions of the alkaline extract: SE5/HE5 (A), SE6/HE6 (B), SE7/HE7 (C), and SE8/HE8 (D). (HE, hard enamel; SE, soft enamel.) At the top of each section is the chromatogram for the first-dimension runs (chromatofocusing). The number on the left at the top of the chromatogram indicates the absorbance at $280 \mathrm{~nm}$. Labeled arrows at the top of each chromatogram indicate that the chromatofocusing column was run for $140 \mathrm{~min}$. Starting on the upper left and moving to the right and then diagonally down is the $\mathrm{pH}$ reading for the material leaving the column. The calibrations for these $\mathrm{pH}$ readings are on the right and range from 4 to 9 . Vertical lines extending up to the absorbance line mark tube changes on the collector. Tube changes occurred at every 0.3 decrease in $\mathrm{pH}$. The numbers at the bottom indicate fraction number, with a dot indicating an increase of 1.0 from the previous number or dot. These fraction numbers correspond to the lane numbers of the image gels for the second-dimension run (below).

focusing column without being separated according to their pIs (see fractions 2-5, Fig. 2A; fractions $1-3$, Fig. 3A,B). This problem can be reduced by injecting smaller quantities of protein $(\approx 0.5 \mathrm{mg})$ and by equilibrating samples in chromatofocusing buffer for more than $24 \mathrm{~h}$ at $4^{\circ} \mathrm{C}$ before injecting.

The ProteomeLab PF2D improves our ability to fractionate enamel proteins, which improves our ability to perform a proteomic analysis of the enamel matrix and to isolate specific enamel proteins for structural and functional analyses. In this study, we took advantage of the high reproducibility (as well as the high resolution) of the PF2D system to compare the contents of secretorystage (soft) enamel to postsecretory-stage (hard) enamel. The rationale for doing so is that enamel crystals have an unusually high aspect ratio (length/width) for hydroxyapatite. It is known that the binding of macromolecules to specific crystal surfaces inhibits the addition of new crystal layers in the direction perpendicular to the 

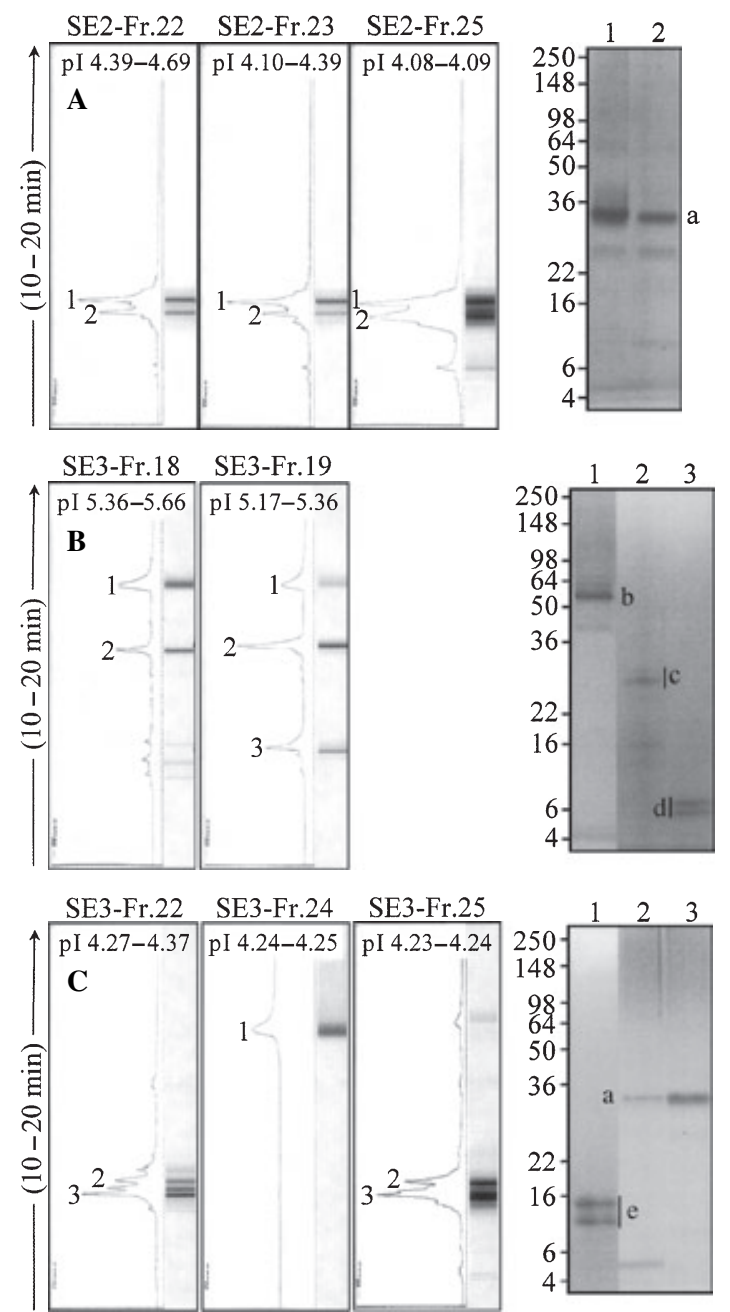

Fig. 4. Sodium dodecyl sulphate-polyacrylamide gel electrophoresis (SDS-PAGE) and N-terminal sequence analysis of enamel components absent from the early maturation stage. The second-dimension chromatograms and image gels for SE2 chromatofocusing peaks 22, 23 and 25 [isoelectric point (pI) range: 4.08-4.69] are shown in (A). The N-terminal sequences of the components in peaks 1 and 2 (a), visualized on silverstained SDS polyacrylamide gels, were both LWHVPHRI, which corresponds to the $32-\mathrm{kDa}$ enamelin. The seconddimension chromatograms and image gels for SE3 chromatofocusing peaks 18 and 19 (pI range: 5.15-5.66) are shown in (B). The SDS polyacrylamide gel for peak 1 is stained with silver, and the SDS polyacrylamide gel for peaks 2 and 3 with stainsall. The N-terminal sequence of the component in peak 1 (b) was DTYKSEIA, which corresponds to serum albumin. The N-terminal sequence of the component in peak 2 (c) was LLANPKGK, which corresponds to the 27- and 29-kDa calcium-binding proteins derived from the ameloblastin $\mathrm{C}$ terminus. The N-terminal sequence of the component in peak 3 (d) was YETAGADE, which is also a cleavage product from the ameloblastin $\mathrm{C}$ terminus, but which has not previously been described. The second-dimension chromatograms and image gels for SE3 chromatofocusing peaks 22, 24, and 25 (pI range: 4.23-4.57) are shown in (C). The SDS polyacrylamide gel for peak 1 is stained with stains-all and the SDS polyacrylamide gel for peaks 2 and 3 are stained with silver. The N-terminal sequence of the component in peak 1 (e) was SRGPxGV, which corresponds to the 13- and 15-kDa ameloblastin C-terminal cleavage products. The $\mathrm{N}$-terminal sequence of the components in peaks 2 and 3 was LWHVPHRI, the 32-kDa enamelin. adsorbing surface (24), and both amelogenins and enamelins have been proposed to regulate crystal habit by inhibiting crystal growth in width and thickness (25).

When maturation-stage enamel crystals are incubated in supersaturated calcium phosphate solutions, no crystal growth is observed unless the maturation-stage enamel is first pretreated with either $8 \mathrm{M}$ urea or sodium hypochlorite to remove the residual protein matrix (26). The theory behind this is that during the transition/early maturation stage, proteases degrade protein inhibitors, allowing maturation to occur (27). This theory, however, must be a simplification, as postsecretory-stage maturation of enamel crystals begins prior to the bulk removal of enamel protein (28). If enamel protein degradation is a prerequisite for crystal maturation, then the inhibitors must be preferentially degraded for the inhibition to be removed when the bulk of the protein remains.

Eight of the $\mathrm{pI}$ fractions containing proteins not found in the hard enamel were fractionated on the second dimension (RP-HPLC), isolated, and characterized by $\mathrm{N}$-terminal sequencing. The five SE constituents absent from the $\mathrm{HE}$ were all glycoproteins derived from enamelin or ameloblastin. These results potentially provide new insight into a paradox of enamel mineralization. During the secretory stage, selected proteins appear to be inhibiting the growth of enamel crystallites in width and thickness. After the end of the secretory stage of amelogenesis, while there is still abundant protein in the enamel matrix among the crystallites, but before the total amount of organic matrix is reduced, there is a substantial amount of mineral deposited on the sides of pre-existing enamel crystallites. How is the inhibition, apparent during the secretory stage, overcome in the early maturation stage? We have not fully answered this question. We did not characterize all of the enamel matrix components that were greatly reduced in the HE relative to the $\mathrm{SE}$, but we did characterize the most prominent. The four protein sequences we characterized were acidic, glycosylated, stains-all positive cleavage products of enamelin and ameloblastin. The 32-kDa enamelin, having three $\mathrm{N}$-linked glycosylations and two phosphoserines, was previously proposed to be the matrix component that adheres to the sides of secretorystage enamel crystallites (13). The C-terminal ameloblastin cleavage products all contain a sulfated O-linked glycosylation (19). The 27- and 29-kDa $(23,29)$ and $13-$ and $15-\mathrm{kDa}$ ameloblastin $\mathrm{C}$-terminal cleavage products have been implicated in $\mathrm{Ca}^{2+}$ binding (19). This is the first report to identify the 6- and $8-\mathrm{kDa}$ ameloblastin cleavage products, but they are subsets of the 13-, 15-, $27-$, and $29-\mathrm{kDa}$ products, and their properties, such as acidic pIs, are similar to the other ameloblastin C-terminal cleavage products.

Selective degradation of the enamel matrix has long been suspected because the amino acid composition of the bulk organic matrix changes during maturation. Based upon similarities of amino acid composition, enamelin degradation products were believed to comprise a disproportionate amount of the residual protein in the mature enamel (30). The term enamelin, however, has since changed from describing a poorly defined mixture of 
proteins to a specific gene product. Our findings suggest that the glycosylated domains from the non-amelogenin proteins are preferentially lost immediately following the secretory stage, and their absence correlates with the onset of enamel maturation, when total enamel protein concentrations are still high. The fact that enamelin and ameloblastin drop below detection earlier than the amelogenins is not necessarily caused by selective degradation, because amelogenins are present at higher levels and may persist for longer, despite being degraded at rates comparable to those of the non-amelogenins.

Acknowledgements - We thank Mr Tom Forton, Manager of the Michigan State University Meat Laboratory, and members of the Michigan State University Department of Animal Science for their kind assistance in obtaining fresh developing molars from pigs slaughtered at their facility. We thank Dr Myron Crawford, director of W. M. Keck Foundation Biotechnology Resource Laboratory at Yale University, and Nancy Williams, for the protein sequencing. This investigation was supported by USPHS Research Grants DE12769, DE15846, and DE11301 from the National Institute of Dental and Craniofacial Research, National Institutes of Health, Bethesda, MD 29892, USA.

\section{References}

1. Simmer JP, Fincham AG. Molecular mechanisms of dental enamel formation. Crit Rev Oral Biol Med 1995; 6: 84-108.

2. Fincham AG, Moradian-Oldak J, Simmer JP. The structural biology of the developing dental enamel matrix. J Struct Biol 1999; 126: 270-299.

3. WitKop CJ Jr, SAUK JJ Jr. Heritable defects of enamel. In: Stewart RE, Prescott GH, eds. Oral facial genetics. St Louis: C.V. Mosby Co., 1976; 151-226.

4. Yamakoshi Y, Hu JC-C, Ryu OH, Tanabe T, Oida S, Fukae M, SimMER JP. A comprehensive strategy for purifying pig enamel proteins. In: Kobayashi I, Ozawa H, eds. Biomineralization: formation, diversity, evolution and application. Hadano: Tokai University Press, 2004; 326-332.

5. Fukae M, Ijiri H, Tanabe T, Shimizu M. Partial amino acid sequences of two proteins in developing porcine enamel. J Dent Res 1979; 58: 1000-1001.

6. Shimizu M, Tanabe T, Fukae M. Proteolytic enzyme in porcine immature enamel. J Dent Res 1979; 58: 782-789.

7. Fukae M, Tanabe T, Ijiri H, Shimizu M. Studies on porcine enamel proteins: a possible original enamel protein. Tsurumi $U$ Dent J 1980; 6: 87-94.

8. Fukae M, Shimizu M. Amino acid sequence of the main component of porcine enamel proteins. Jpn J Oral Biol 1983; 25: 29.

9. Yamakoshi Y, Tanabe T, Fukae M, Shimizu M. Amino acid sequence of porcine $25 \mathrm{kDa}$ Amelogenin. In: FEARnHEAD RW, ed. Tooth enamel V. Tokyo: Florence Publishers, 1989; 314 321 .

10. Yamakoshi Y, Tanabe T, Fukae M, Shimizu M. Porcine amelogenins. Calcif Tissue Int 1994; 54: 69-75.

11. Fukae M, Tanabe T. Nonamelogenin components of porcine enamel in the protein fraction free from the enamel crystals. Calcif Tissue Int 1987; 40: 286-293.

12. Uchida T, Tanabe T, Fukae M, Shimizu M, Yamada M, Miake K, Kobayashi S. Immunochemical and immunohistochemical studies, using antisera against porcine $25 \mathrm{kDa}$ amel- ogenin, $89 \mathrm{kDa}$ enamelin and the 13-17 kDa nonamelogenins, on immature enamel of the pig and rat. Histochemistry 1991; 96: $129-138$.

13. Tanabe T, Aoba T, Moreno EC, Fukae M, Shimizu M. Properties of phosphorylated $32 \mathrm{kd}$ nonamelogenin proteins isolated from porcine secretory enamel. Calcif Tissue Int 1990; 46: $205-215$.

14. Uchida T, Tanabe T, Fukae M, Shimizu M. Immunocytochemical and immunochemical detection of a $32 \mathrm{kDa}$ nonamelogenin and related proteins in porcine tooth germs. Arch Histol Cytol 1991; 54: 527-538.

15. Yамаковнi Y. Carbohydrate moieties of porcine $32 \mathrm{kDa}$ enamelin. Calcif Tissue Int 1995; 56: 323-330.

16. Fukae M, Tanabe T, Murakami $C$, Dohi N, Uchida $T$, Shimizu M. Primary structure of the porcine $89-\mathrm{kDa}$ enamelin. Adv Dent Res 1996; 10: 111-118.

17. Yamakoshi Y, Pinheiro FH, Tanabe T, Fukae M, Shimizu M. Sites of asparagine-linked oligosaccharides in porcine 32 kDa enamelin. Connect Tissue Res 1998; 39: 39-46.

18. Uchida T, Fukae M, Tanabe T, Yamakoshi Y, Satoda T, Murakami C, Takahashi O, Shimizu M. Immunochemical and immunocytochemical study of a $15 \mathrm{kDa}$ non-amelogenin and related proteins in the porcine immature enamel: proposal of a new group of enamel proteins sheath proteins. Biomed Res 1995; 16: 131-140.

19. Yamakoshi Y, Tanabe T, Oida S, Hu CC, Simmer JP, Fukae M. Calcium binding of enamel proteins and their derivatives with emphasis on the calcium-binding domain of porcine sheathlin. Arch Oral Biol 2001; 46: 1005-1014.

20. Tanabe T. Purification and characterization of proteolytic enzymes in porcine immature enamel. Tsurumi $U$ Dent $J 1984$; 10: $443-452$.

21. Simmer JP, Fukae M, Tanabe T, Yamakoshi Y, Uchida T, Xue J, Margolis HC, Shimizu M, Dehart BC, Hu CC, BARTLETT JD. Purification, characterization, and cloning of enamel matrix serine proteinase 1. J Dent Res 1998; 77: 377386.

22. Ryu OH, Hu JC-C, Yamakoshi Y, Villimain JA, CaO X, Zhang CH, Bartlett JD, Simmer JP. KLK-4 activation, glycosylation, activity, and expression in prokaryotic and eukaryotic hosts. Eur J Oral Sci 2002; 110: 358-365.

23. Murakami C, Dohi N, Fukae M, Tanabe T, Yamakoshi Y, Wakida K, Satoda T, Takahashi O, Shimizu M, Ryu OH, SimMER JP, UCHIDA T. Immunochemical and immunohistochemical study of 27 and $29 \mathrm{kDa}$ calcium binding proteins and related proteins in the porcine tooth germ. Histochem Cell Biol 1997; 107: 485-494.

24. AdDADi L, Weiner S. Stereochemical and structural relations between macromolecules and crystals in biomineralization. In: ManN S, WebB J, Williams RJP, eds. Biomineralization, chemical and biochemical perspectives. New York: Weinheim, 1989; 133-152.

25. Doi Y, Eanes ED, Shimokawa H, Termine JD. Inhibition of seeded growth of enamel apatite crystals by amelogenin and enamelin proteins in vitro. $J$ Dent Res 1984; 63: 98-105.

26. Robinson C, Kirkham J, Stonehouse NJ, Shore RC. Control of crystal growth during enamel maturation. Connect Tissue Res 1989; 22: 139-145.

27. Robinson C, Kirkham J, Shore R, eds. Dental Enamel Formation to Destruction. Boca Raton: CRC Press, 1995; 1-272.

28. Sмітн CE. Cellular and chemical events during enamel maturation. Crit Rev Oral Biol Med 1998; 9: 128-161.

29. Fukae M, Tanabe T. ${ }^{45} \mathrm{Ca}$-labeled proteins found in porcine developing dental enamel at an early stage of development. $A d v$ Dent Res 1987; 1: 261-266.

30. Robinson C, Fuchs P, Weatherell JA. The fate of matrix proteins during the development of dental enamel. Calcif Tissue Res 1977; 22: 185-190. 